ISSN 0103-5150

Fisioter. Mov., Curitiba, v. 29, n. 2, p. 317-324, Apr./June 2016

Licenciado sob uma Licença Creative Commons DOI: http://dx.doi.org.10.1590/0103-5150.029.002.A010

\title{
Handgrip strength and muscle fatigue among footwear industry workers
}

\author{
Força de preensão palmar e fadiga muscular \\ em trabalhadores do setor calçadista
}

\author{
Lidiane Angélica Cotelez ${ }^{[a]}$, Maysa Venturoso Gongora Buckeridge Serra ${ }^{[a]}$, Eliane Ramos ${ }^{[b]}$, \\ José Eduardo Zaia ${ }^{[\mathrm{c}]}$, Flávia Oliveira Toledo ${ }^{[\mathrm{d}]}$, Paulo Roberto Veiga Quemelo ${ }^{[\mathrm{a}] *}$ \\ [a] Universidade de Franca (Unifran), Franca, SP, Brazil \\ [b] Universidade Federal Santa Catarina (UFSC), Florianópolis, SC, Brazil \\ [c] Universidade Estadual de Minas Gerais (UEMG), Passos, MG, Brazil \\ [d] Centro Universitário Hermínio da Silveira (UNI IBMR), Rio de Janeiro, RJ, Brazil
}

\begin{abstract}
Introduction: Muscle fatigue can be defined as a decrease in the performance of the neuromuscular system in generating force. This situation is considered a complex physiological process involving various body systems, in order to avoid irreversible damage or even cell death. Objective: The aim of this study was to measure muscle strength in order to assess the level of fatigue among footwear industry workers, and to determine a possible correlation between muscle strength and the perception of reported fatigue. Materials and Methods: The study included 32 male workers from the footwear industry with a mean age of $34.63 \pm$ 11.98 years. The workers performed the handgrip strength test using a handheld dynamometer, and completed the Bipolar Fatigue Questionnaire. Results: The mean result of strength testing was $23.1 \pm 8.3 \mathrm{kgf}$,
\end{abstract}

\footnotetext{
"LAC: MSc student, e-mail: lidianecotelez@hotmail.com MVGBS: PhD student, e-mail: ma_buckeridge@hotmail.com ER: MSc, e-mail: eramos1@catamount.wcu.edu JEZ: PhD, e-mail: jose.zaia@fespmg.edu.br FOT: PhD, e-mail: flaviatoledo.phd@gmail.com PRVQ: PhD, e-mail: pquemelo@hotmail.com
} 
and the mean score of the fatigue questionnaire was $2.28 \pm 0.93$ points. However, a low correlation was observed between the results of the fatigue questionnaire and the strength test results. Conclusion: The grip strength results of the footwear workers were below the values for the general Brazilian population, a fact that may indicate potential muscle fatigue. However, a low correlation with the perception of fatigue was indicated by the questionnaire.

Keywords: Fatigue. Muscle fatigue. Handgrip strength. Worker's health.

\section{Resumo}

Introdução: A fadiga muscular pode ser definida como uma diminuição na capacidade do sistema neuromuscular em conseguir gerar força. Essa condição é considerada como um processo fisiológico complexo que envolve diversos sistemas do organismo, com o objetivo de evitar danos irreversíveis ou, até mesmo, morte celular. Objetivo: Avaliar a força de preensão palmar em trabalhadores do setor calçadista e verificar a existência de correlação entre a força muscular e a percepção da fadiga relatada. Materiais e Métodos: Participaram do estudo 32 trabalhadores do sexo masculino, com média de idade de 34,63 $\pm 11,98$ anos e que atuavam no setor calçadista. Os trabalhadores realizaram o teste de contração voluntária máxima (CVM) utilizando um dinamômetro hidráulico de preensão palmar e responderam ao questionário Bipolar de Fadiga. Durante o teste, cada trabalhador executava três repetições da CVM e a média das medidas era obtida. Resultados: A força muscular apresentou uma média de 23,1 $\pm 8,3 \mathrm{kgf}$ e o escore do questionário de fadiga apresentou uma média de 2,28 \pm 0,93 pontos. Entretanto, foi observada baixa correlação entre as medidas da CVM e os escores do questionário utilizado. Conclusão: Os trabalhadores do setor calçadista apresentaram força muscular abaixo do nível da população brasileira, o que sugere a ocorrência de fadiga muscular, porém, observou-se baixa correlação com a percepção de fadiga relatada.

Palavras-chave: Fadiga. Fadiga muscular. Dinamômetro de preensão palmar. Saúde do trabalhador.

\section{Introduction}

The footwear industry is an important economic sector in Brazil (1). Despite the increasing industrialization process, the line of production of the footwear industry still involves a high demand of muscle strength and repetitive motions that can lead to a state of fatigue (2-4). The work volume and the pressure to increase production, alternating shifts, the existence of physical risks and the lack of independence can be associated with this condition (5). Workers with fatigue have low productivity, with a higher risk of accidents at work, which can affect the worker's health $(6,7)$.

Muscle fatigue can be defined as any decrease in the capacity of the neuromuscular system to generate force (8). This condition can promote changes in the propagation of muscle action potentials, in the contractile muscle mechanisms and, also, in ion concentration, which are important for sustaining muscle contraction (9). Additionally, muscle fatigue is considered a complex physiological process, which involves a variety of body systems with the goal of avoiding irreversible damage or even cell death (10).
The understanding of the causes of muscle fatigue is a subject area that, although increasingly studied, is still controversial. Due to the multidimensional concept that includes physiological and psychological aspects, quantifying the symptoms that precede the reduction in the ability of the muscle to sustain a level of strength is a highly complex problem in the clinical setting (8).

Muscle strength is an important component related to subject performance. The increase or decrease in muscle strength can influence the productivity of workers and contribute to the development of musculoskeletal disorders in different work settings (11, 12). Thus, the measurement of grip strength permits us to establish a parameter of the functional integrity of the upper limbs (13).

In ergonomic practice, questionnaires and ergonomic tools are frequently used to evaluate fatigue and working conditions, due to their practicality and low cost $(4,5)$. Although many instruments have been validated, some degree of subjectivity is inherent to the questionnaires due to the self-answer provided by the worker at the time of questionnaire application 
or interview. Therefore, the objective of the present study was to evaluate grip strength and its correlation with the perception of fatigue reported by workers in the footwear industry.

\section{Methods}

Participants and location of the study

This was an observational and cross-sectional study conducted in order to assess grip strength and its correlation with workers' perception of muscle fatigue in the footwear industry in the city of Franca.

The study included 32 male workers with a mean age of $34.63 \pm 11.98$ years. The mean height of the participants was $1.80 \pm 0.08 \mathrm{~m}$, the mean weight was $81.29 \pm 16.92 \mathrm{~kg}$, and the mean body mass index was $25 \pm 4.29 \mathrm{~kg} / \mathrm{m}^{2}$. Newly hired workers, those with less than a year on the job, those with hand injury or pain at the time of testing, and those who refused to participate voluntarily were excluded from the study. The study was approved by the Research Ethics Committee of the University of Franca (CAAE: 24308313.5.0000.5495), and all subjects gave written informed consent to participate.

\section{Dynamometer}

A Jamar ${ }^{\circledR}$ handgrip dynamometer was used to determine handgrip strength. The device consists of a hydraulic system for the measurement of maximum voluntary contraction (MVC) of palmar prehension and is appropriate for determining the amount of force exerted (8.9). The dynamometer provides a measure of the handgrip MCV in kilogram force $(0$ to $90 \mathrm{kgf}$ ) and pound force ( 0 to $200 \mathrm{lbs}$ ). The device is inexpensive, can be easily transported, can be applied rapidly, and is easy to handle $(14,15)$. The dynamometer is considered to be the "gold standard" for the measurement of grip strength and is recommended by the American Society of Hand Therapists (ASHT) as a widely used reliable assessment tool $(14-17)$.

\section{Bipolar Questionnaire Fatigue}

The Bipolar Fatigue Questionnaire consists of 14 questions that are geared to measure worker's fatigue. The scores of the instrument range from
1 to 7 points. The questions are related to the degree of tiredness, poor concentration, nervousness, compromised productivity, eye strain, pain in the muscles of the neck/shoulders, back pain, lower back pain, thigh pain, leg pain, foot pain, headache, pain in the right arm/wrist/hand, and pain in the left arm/wrist/hand. The subject is instructed to state what he is feeling at the time of the interview. For example, "Question 1 - How much are you feeling rested (1-2-3-4-5-6-7) or tired? Values closer to 1 indicate "no fatigue" and values closer to 7 indicate "higher level of fatigue" like a Likert scale (18). According to the questionnaire score, the fatigue of the participants was classified as: 1 ---- | 3 absence of fatigue, 3 ---- | 5 moderate fatigue, and 5 ----- 7 intense fatigue. The questionnaire should not be applied to workers who have been performing their function for less than two months or who have returned from vacation within the last three weeks (18).

\section{Data collection}

Two examiners properly trained in operating the instruments of measurement carried out the strength and fatigue assessments. The participants answered the Bipolar Fatigue Questionnaire and a questionnaire regarding sociodemographic and occupational information, with questions related to age, marital status, job function and time of work in the footwear industry. Subsequently, the examiners determined the handgrip MVC. In order to measure grip strength, the participants were placed in a sitting position with the shoulder adducted and neutrally rotated, elbow flexed at 90 degrees, forearm in neutral position, wrist between 0 and 30 degrees of extension, 0 to 15 degrees of ulnar deviation, and forearm unsupported, according to ASHT recommendations (19). The dynamometer handle was adjusted to the second position according to the size of the workers' hand, and the test was performed only on the dominant side. The examiner provided verbal instruction by asking the participant to maximally grip the handle after the command "go!" (20). This procedure was repeated three times, with an interval of one minute between each measurement to assist in muscle strength recovery (21). The average value of the three measurements of the isometric MVC was recorded in kilogram-force (kgf). 
Following the MVC measurement, the participant answered the Bipolar Fatigue Questionnaire in a quiet environment provided by the company. Both instruments were applied on the same day of the week (Friday), in the morning, before the workers started their work day.

\section{Data analysis}

The Excel spreadsheet was used to obtain the mean, standard deviation, and absolute and relative values. The mean and standard deviation were used to express the results obtained with the strength and fatigue questionnaire test. Correlations were tested using Pearson's correlation coefficient. The level of significance adopted was $p<0.05$. All analyses were performed using the STATISTICA data analysis software system, version 7 (StatSoft, Inc., 2004).

The degree of correlation was classified as follows: very low ( 0.20 ), low ( 0.21 to 0.40 ), moderate ( 0.41 to 0.60$)$, high ( 0.61 to 0.80$)$, and very high (0.80 to 1.0$)(22)$.

\section{Results}

The majority of the workers were married (53.13\%), performed cutting functions (31.25\%), had been working in the footwear industry for 1-5 years (50.0\%), and 22 (68.75\%) reported having never been temporarily away from work (Table 1 ).

The grip strength mean value was $23.1 \pm 8.3$ kgf. The mean grip strength was $23.1 \pm 8.3 \mathrm{kgf}$ (range: 5.0-36.7 kgf).

The mean score in the Bipolar Fatigue Questionnaire was $2.28 \pm 0.93$ points, with 26 $(81.25 \%)$ workers being classified as having no fatigue, $6(18.75 \%)$ as having moderate fatigue, and none as being severely fatigued.

Figure 1 shows the dispersion of the values of the correlation between grip strength values and fatigue questionnaire scores. This analysis showed a low and nonsignificant correlation $(\mathrm{p}=0.199, \mathrm{r}=0.233)$.
Table 1- Distribution of workers according to marital status, job function and time of work in the footwear industry

\begin{tabular}{|c|c|c|}
\hline Variables & $\mathrm{N}$ & $\%$ \\
\hline \multicolumn{3}{|l|}{ Marital status } \\
\hline Married & 17 & $53.13 \%$ \\
\hline Single & 14 & $43.75 \%$ \\
\hline Divorced & 1 & $3.13 \%$ \\
\hline Widowed & 0 & $0.00 \%$ \\
\hline \multicolumn{3}{|l|}{ Job function } \\
\hline Cutting & 10 & $31.25 \%$ \\
\hline Preparation & 1 & $3.13 \%$ \\
\hline Stitching & 0 & $0.00 \%$ \\
\hline Finishing & 6 & $18.75 \%$ \\
\hline Mounting & 7 & $21.88 \%$ \\
\hline Others & 8 & $25.00 \%$ \\
\hline \multicolumn{3}{|c|}{ Time of work in the footwear industry } \\
\hline $1-5$ years & 16 & $50.00 \%$ \\
\hline $6-10$ years & 5 & $15.63 \%$ \\
\hline $11-15$ years & 6 & $18,75 \%$ \\
\hline $16-20$ years & 2 & $6.25 \%$ \\
\hline $21-25$ years & 1 & $3.13 \%$ \\
\hline $26-30$ years & 2 & $6.25 \%$ \\
\hline
\end{tabular}




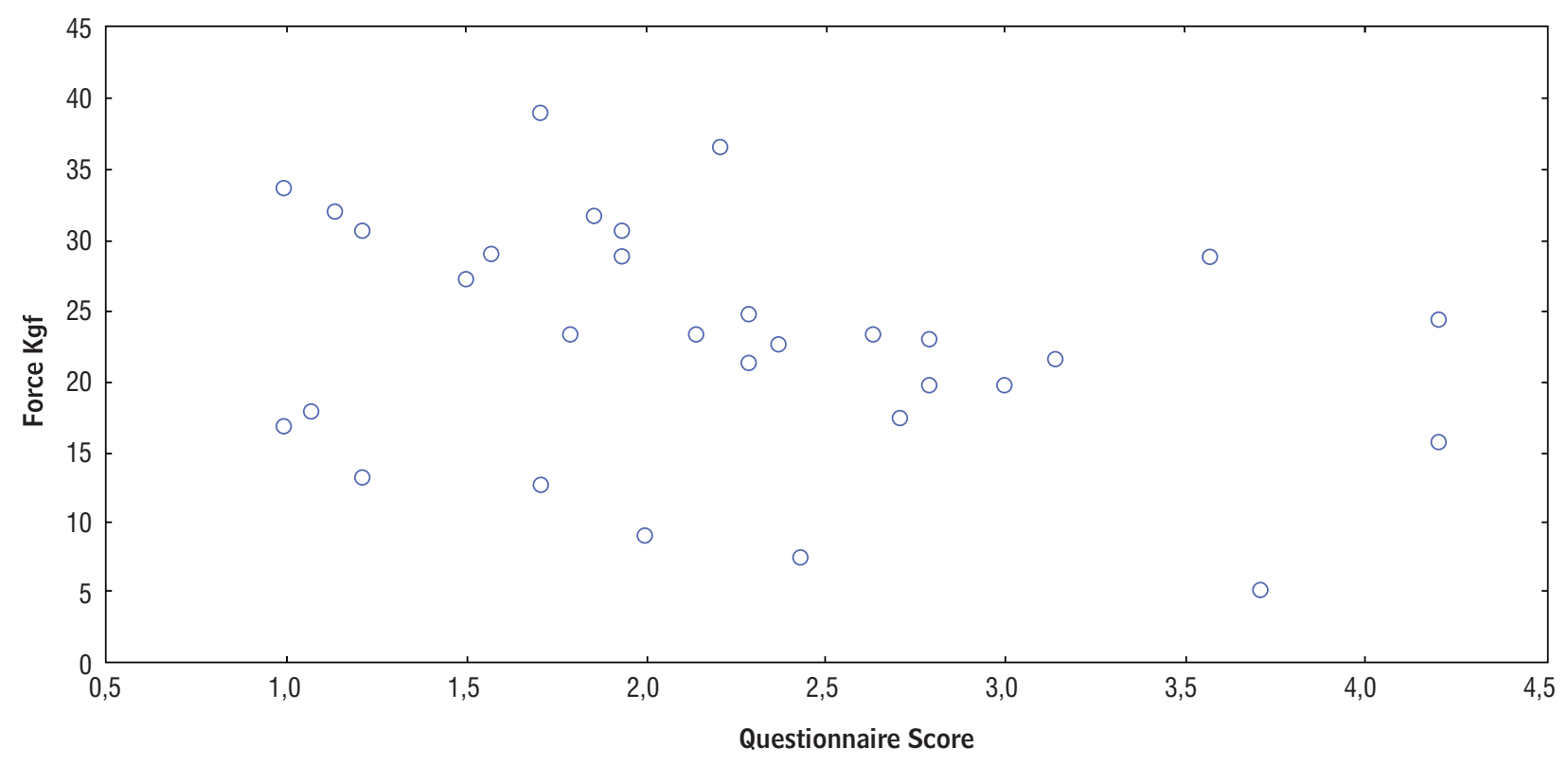

Figure 1 - Scatter plot correlation between grip force (kgf) and scores of fatigue questionnaire

\section{Discussion}

The present results indicate that workers in the footwear industry have reduced muscle grip strength compared to the normal values for healthy populations $(23,24)$. The fatigue is related to decreased strength sensation, the need for rest, as well as to the muscular response and the inability of skeletal muscle to maintain the same performance (25). However, even when the grip strength is below normal limits, the workers can still perform all required tasks (26). The reduction in grip strength in the industrial sector, and among the production line workers in particular, can be related to performing repetitive movements, engaging in awkward postures, lack of available ergonomic equipment, and lack of resting breaks $(4,11,27)$.

The hands are an essential tool to perform work tasks and are able to exert forces that can exceed $445 \mathrm{~N}$ or $45 \mathrm{~kg}(28,29)$. According to Napier (30), the thumb is largely responsible for hand efficiency and, depending on the type of activity performed, the hands may acquire a great increase in strength. However, performing the same task for long periods of time without resting intervals can lead to fatigue and, as a result, decreased muscle strength $(31,32)$.
Handgrip strength reaches maximum values during adulthood. After this period, a gradual decline occurs that may be related to the loss of muscle mass $(13,33)$. The workers who participated in the present study were males and, on average, young adults according to the WHO. This negatively impacts the interpretation of the results and shows the early loss of muscle strength in this population. Thus, the early loss of muscle strength can be an important indicator of the presence of early fatigue due to overuse, which can contribute to soft tissue damage. The early detection and assessment of muscle weakness can be an important sign of the occurrence of muscle fatigue. Therefore, it is recommended ergonomic interventions and preventive measures to be adopted in order to avoid possible soft tissue injury and to prevent occupational diseases in workers.

The assessment of isometric handgrip MVC permits the analysis of adaptations of extrinsic and intrinsic hand muscles exposed to loads during a specific task (34). In the present study the hydraulic handgrip dynamometer was used since it can be applied to a large number of individuals from different populations, such as healthy individuals $(23,24)$ and those affected by neurological (35), orthopedic (36) psychiatric (37), and heart diseases (38).

Early muscle fatigue can be a debilitating symptom. Its evaluation allows to characterize and quantify this symptom, and thus serves as a resource for clinical diagnosis and for the selection of the best treatment strategy for the patient and for the determination of 
whether the chosen treatment is effective (39). It can be assessed subjectively through self-report measures with the use of questionnaires or scales based on the perception of the individual (40).

On the other hand, the results of the fatigue analysis using the Bipolar Fatigue Questionnaire indicated that $81.25 \%$ of the workers had no fatigue, $18.75 \%$ had moderate fatigue, and none of the workers was rated as severely fatigued. These results may be associated with the workers' age (young adults) and their time of work in the footwear industry (less than five years). It is possible that young workers with little time of work feel inhibited or uncomfortable in answering the questionnaire. Although this instrument is widely used in ergonomic practice by companies, no scientific studies are available for comparison with the results of the present study.

The present findings showed a low correlation between measures of muscle strength and the perception of fatigue obtained with the Bipolar Fatigue Questionnaire. This low correlation may indicate the necessity to pay careful attention during the application and interpretation of questionnaires in the workplace. Self-applicable instruments are commonly used to assess the workers' conditions. Questionnaires are easy and fast, are of low financial cost, and can be applied instantly to a large number of individuals $(41,42)$. However, these instruments are often subjective, and the worker's response can be influenced by several factors. Among them, the workers may be apprehensive about reporting their own condition due to the fear of possibly represent a problem for the company although the study had kept their information private.

Given the results of the present study, it is necessary to consider some limitations: there is no study about the psychometric properties of the Bipolar Questionnaire Fatigue test; there are many questions about pain intensity and the lack of a specific question about fatigue intensity in the Bipolar Fatigue Questionnaire; the questionnaire was applied only once to the workers; the small sample size of this study; and the lack of scientific studies on the measurement of isometric MVC with a hydraulic handgrip dynamometer in this population (footwear workers). Therefore, there is a need for more studies evaluating the muscle fatigue of workers in order to better understand the mechanisms and to propose intervention strategies for the prevention of this phenomenon.

\section{Conclusion}

The handgrip strength values for the workers studied here were lower than those for the general Brazilian population, a fact that may indicate possible muscle fatigue among these workers. No significant correlation between grip strength and reported perception of fatigue was observed. These findings suggest the necessity to pay careful attention in interpreting the results obtained from questionnaires.

\section{References}

1. Abicalçados. Statistical Primer 2011 [Internet]. Novo Hamburgo: Abicalçados; 2011 [cited 2014 June 04]. Available from: http://www.abicalcados.com.br

2. Zorzanelli RT. A síndrome da fadiga crônica: apresentação e controvérsias. Psicol Estud. 2010; 15(1):65-71.

3. Quemelo PRV, Arar MB, Coelho AR, Gottardo D. Avaliação ergonômica e prevalência das doenças relacionadas ao trabalho em empresas calçadistas. Colloquium Vitae. 2009;1(2):94 - 9.

4. Lourinho MG, Negreiros GR, Almeida LB, Vieira ER, Quemelo PRV. Riscos de lesão musculoesquelética em diferentes setores de uma empresa calçadista. Fisioter Pesq. 2011; 18(3):252 - 7.

5. Almeida LB, Bachur JÁ, Quemelo PRV. Análise ergonômica do setor de prensados para a produção de solados em uma empresa calçadista da cidade de Franca-SP. Investigação. 2010;10:69-73.

6. Oliveira JRS, Viganó MG, Lunardelli MCF, Câneo LC, Goulart Júnior E. Fadiga no trabalho: como o psicólogo pode atuar? Psicol Estud [online]. 2010; 15(3):633 - 8.

7. Ferreira LRC, Martino MMF. Padrão de sono e sonolência do trabalhador estudante de enfermagem. Rev Esc Enferm USP. 2012; 46(5):1170 - 83.

8. Zwarts MJ, Bleijenberg G, van Engelen BG. Clinical neurophysiology of fatigue. Clin Neurophysiol. 2008; 119(1):2-10.

9. Boyas S, Guével A. Neuromuscular fatigue in healthy muscle: Underlying factors and adaptation mechanisms. Ann Phys Rehab Med. 2011; 54(2):88-108. 
10. Baron B, Noakes TD, Dekerle J, Moullan F, Robin S, Matran R, et al. Why does exercise terminate at the maximal lactate steady state intensity? Brit J Sports Med. 2008; 42(10):828 - 33.

11. Quemelo PRV, Ravagnani ILM, Neiva CM, Zaia JE. Association of the musculoskeletal disorders with activity performed in workplace. Rev Bras Ci e Mov. 2013; 21(4):166 - 71.

12. Fontes CF, Ravagnani ILM, Zaia JE, Quemelo PRV. Comparação da sobrecarga biomecânica em funcionários que executam suas tarefas na posição ortostática e sentada. Rev Bras Ci e Mov. 2013; 21(1):10-15.

13. Oliveira FBD, Moreira D. Força de preensão palmar e diabetes mellitus. Rev Bras Clin Med. 2009; 7:251 - 5.

14. Chengalur SN, Smith GA, Nelson RC, Sadoff AM. Assessing sincerity of effort in maximal grip strength tests. Amer Jour Phys Med Rehab. 1989;68:73-80.

15. Shechtman O, Gestewitz L, Kimble C. Reliability and validity of the DynEx dynamometer. J Hand Ther. 2005; 18(3):339 - 47.

16. Bohannon RW, Schaubert KL. Test-retest reliability of grip-strength measures obtained over a 12-week interval from community-dwelling elders. J Hand Ther. 2005; 18(4):426 - 7.

17. Bohannon RW, Peolsson A, Massy-Westropp N, Desrosiers J, Bear-Lehman J. Reference values for adult grip strength measured with a Jamar dynamometer: a descriptive meta-analysis. Physiotherapy. 2006; 92:11 - 5.

18. Couto HA. Ergonomia Aplicada ao Trabalho: Manual técnico da Máquina Humana. Belo Horizonte: Ergo Editora, v. 02; 1996.

19. Moreira D, Álvarez RRA, Gogoy JR, Cambraia AN. Abordagem sobre preensão palmar utilizando o dinamômetro JAMAR ${ }^{\circledR}$ : uma revisão de literatura. Rev Bras Ci. e Mov. 2003; 11(2):95 - 9.

20. Figueiredo IM, Sampaio RF, Mancini MC, Silva FCM, Souza MAP. Teste de força de preensão utilizando o dinamômetro Jamar. Acta Fisiátrica. 2007; 14(2):104 - 10.

21. Alencar MA, Dias JMD, Figueiredo LC, Dias RC. Força de preensão palmar em idosos com demência: estudo da confiabilidade. Rev Bras Fisio. 2012; 16(6):510-4.
22. Ajzen, Icek, Martin Fishbein. Understanding attitudes and predicting social behaviour. Englewood Cliffs, NJ: Prentice-Hall; 1980.

23. Mathiowetz V, Weber K, Volland G, Kashman N. Reliability and validity of grip and pinch strength evaluations. J Hand Surg Am. 1984; 9(2):222-226.

24. Bohannon RW. Reference values for extremity muscle strength obtained by hand-held dynamometry from adults aged 20 to 79 years. Arch Phys Med Rehabil. 1997;78(1):26-32.

25. Associação Brasileira de Cuidados Paliativos. Consenso Brasileiro de Fadiga. 2010; 2 (3 Suppl 1).

26. Mathiowetz V. Role of physical performance component evaluations in occupational therapy functional assessment. Am J Occup Ther. 1993; 47(3):225-30.

27. Leyk D, Rohde U, Erley O,Gorges W, Wunderlich $\mathrm{M}$,Rüther T, et al. Recovery of hand grip strength and hand steadiness after exhausting manual stretcher carriage. Eur J Appl Physiol. 2006; 96(5):593-9.

28. Imrhan SN, Loo CH. Trends in finger pinch strength in children, adults, and the elderly. Hum Factors. 1989; 31(6):689-701.

29. Smith LK, Weiss EL, Lehmkuhl LD. Punho e mão. In: Cinesiologia clínica de Brunnstrom. Barueri: Manole; 1997. p. 209-56.

30. Napier JR. The prehensile movements of the human hand. J Bone Joint Surg Br. 1956; 38B(4):902-13.

31. Tiwari PS, Gite LP, Majumder J, Pharade SC, Singh VV. Push/pull strength of agricultural workers in central India. Int J Ind Ergon. 2010; 40(1):1-7.

32. Werle S, Goldhahn J, Drerup S, Simmen BR, Sprott H, Herren DB. Age- and gender-specific normative data of grip and pinch strength in a healthy adult Swiss population. J Hand Surg Eur. 2009; 34(1):76-84.

33. Comi G, Leocani L, Rossi P, Colombo B. Physiopathology and treatment of fatigue in multiple sclerosis. J Neurol. 2001; 248(3):174 - 9.

34. Gonçalves GH, Gomes DA, Teixeira MDM, Shimano SGN, Shimano AC, Fonseca MCR. Força de preensão palmar e pinça digital em diferentes grupos de pilotos da Academia da Força Aérea brasileira. Fisioter Pesq. 2010; 17(2):141-6. 
35. Graciani Z, Santos S, Macedo-Souza LI, Monteiro CB, Veras MI, Amorim S, et al. Motor and functional evaluation of patients with spastic paraplegia, optic atrophy, and neuropathy (SPOAN). Arq Neuropsiquiatr. 2010; 68(1):3-6.

36. Gündüz R, Malas FÜ, Borman P, Kocaoğlu S, Özçakar L. Physical therapy, corticosteroid injection, and extracorporeal shock wave treatment in lateral epicondylitis. Clin 2012; 31(5):807-12.

37. Blankevoort CG, van Heuvelen MJ, Scherder EJ. Reliability of six physical performance tests in older people with dementia. Phys Ther. 2013; 93(1):69-78.

38. Loncar G, Bozic B, von Haehling S, Düngen HD, Prodanovic N, Lainscak M, et al. Association of adiponectin with peripheral muscle status in elderly patients with heart failure. Eur J Intern Med. 2013; 24(8):818-23.
39. Pavan K, Schmidt K, Ariça TA, Mendes MF, Tilbery CP, Lianza S. Avaliação da fatigabilidade em pacientes com esclerose múltipla através do dinamômetro manual. Arq Neuropsiquiatr. 2006; 64(2):283 - 6.

40. Silva JA, Ribeiro-Filho NP. Avaliação e mensuração de dor: pesquisa, teoria e prática. Ribeirão Preto: Funpec, 2006.

41. Krupp LB, Larocca NC, Muir-Nash J, Steinberg AD. The fatigue severity scale: application to patients with multiples esclerosis and systemic lupus erythematosus. Arch Neurol. 1989; 46(10):1121 - 3.

42. Kos D, Nagels G, D’Hooghe B, Duportail M, Kerckhofs E. A rapid screening tool for fatigue impact in multiple sclerosis. BMC Neurology. 2006; 6:27.

Received: $10 / 27 / 2014$

Recebido: 27/10/2014

Approved: $12 / 03 / 2015$

Aprovado: 03/12/2015 